\title{
The Rule of Law and Foreign Direct Investment
}

\author{
Xiujie ZHANG ${ }^{1}$, Weihua $\mathrm{LIU}^{2, *}$ \\ ${ }^{1}$ School of Law, Macau University of Science and Technology, Macao, China \\ ${ }^{2}$ School of Business, Macau University of Science and Technology, Macao, China \\ "Corresponding author.Email: a_s_lewis@hotmail.com
}

\begin{abstract}
Foreign Direct Investment (FDI) plays an import role in economic growth. Using international panel data, this paper investigates the effects of Rule of Law on FDI inflows. The research shows that the Rule of Law has positive effects on inward FDI, and Absence of Corruption, Effective Regulation Enforcement, and Open Government are the most significant factors of Rule of Law to facilitate FDI.
\end{abstract}

Keywords: rule of law, foreign direct investment, FDI, corruption, regulation

\section{INTRODUCTION}

The Rule of Law is an important goal for modern public governance, while the Foreign Direct Investment (FDI) plays an important role in economic growth. Although some scholars have studied their relations, the causal relationship is not so clear-cut. Besides since many scholars study this topic under a generic concept of the Rule of Law, it is necessary to deepen our understanding by decomposing this concept and study the relations between each factor and FDI.

In general, most literature admits the positive role of Rule of Law on inward Foreign Direct Investment. But some authors discover that weak Rule of Law may attract FDI in some special circumstances.

On the macro level, Busse and Hefeker's ${ }^{[1]}$ research shows that law and order is positively associated with FDI flows, indicated by an estimated coefficient that is significant at least at the $10 \%$ level. Gani ${ }^{[2]}$ presents "panel data estimates of the relationship between indicators of governance and FDI using a sample of countries from Asia and Latin America" and provides strong confirmation that the rule of law is positively correlated with FDI. $\mathrm{Li}^{[3]}$ discovers that "countries with better rule of law offer lower levels of tax incentives, and the effect is stronger for more democratic countries". Oliva and Rivera-Batiz ${ }^{[4]}$ offer evidence that "the rule of law influences growth indirectly by encouraging foreign direct investment". Alexander ${ }^{[5]}$ "examines the role a country's respect for the rule of law plays in its ability to attract FDI" and finds "investors prefer countries that protect contract, property, and physical integrity rights".
On the micro level, Jensen ${ }^{[6]}$ finds that "CEOs prefer countries that provide investment safety linked to adherence to rule of law, upholding of private property rights, use of a relatively efficient and effective court system". Henisz ${ }^{[7]}$ studies the institutional environment for multinational investment by analysing "a sample of 3,389 overseas manufacturing operations by 461 firms in 112 countries" and "posits that the effect of political hazards on the choice of market entry mode varies across multinational firms based on the extent to which they face expropriation hazards from their potential joint-venture partners in the host country (the level of contractual hazards). As political hazards increase, the multinational faces an increasing threat of opportunistic expropriation by the government."

Some scholars pay their attention to the FDI into developing countries. Using panel data analysis, Hossain and Rahman ${ }^{[8]}$ attempt to "estimates the significance of governance on foreign direct investment for a sample of 80 developing countries from 1998 to 2014". Their research implies that "a one standard deviation improvement in ... rules of law ... increases FDI by ..23.1\%." And Wilhelms ${ }^{[9]}$ shows that a strong rule of law has high and robust positive correlation with FDI in emerging economies. Using a fixed effect model for panel data "on foreign direct investment inflows in 15 Asian economies for the period 1996-2007" with heteroskedasticity corrected standard errors, Mengistu and Adhikary ${ }^{[10]}$ reveal that Rule of Law is one key determinant of FDI inflows. Naudé and Krugell [11] "uses a cross-country econometric approach to identify the determinants for foreign direct investment in Africa" and identify rule of law as a robust determinant of FDI. 
Rodríguez-Pose and Cols ${ }^{[12]}$ show that rule of law not only is an important determinant of FDI, and that "their influence on the capacity of African countries to attract FDI is long-lasting". Gangi and Abdulrazak ${ }^{[13]}$ employ "a panel regression model on data from 50 African countries for the period 1996 to 2010 " and find that rule of law has significant effects on foreign direct investment flows to African countries. Epaphra and Massawe ${ }^{[14]}$, using the data of East African countries, articulates that "all things being equal, a stronger rule of law will in principle encourage FDI by ensuring a transparent, stable and predictable environment in which host governments credibly commit to the enforcement of contracts and the protection of property rights and rights of the person". Based on panel data analysis and their survey of US corporations, Staats and Biglaiser ${ }^{[15]}$ find that judicial strength and rule of law elements are important determinants of FDI in Latin America. By conducting a survey of U.S. chief executive officers (the actual decision makers) of corporations that have investments in Latin America, Biglaiser and Staats ${ }^{[16]}$ find that "investment risk related to property-rights protection, adherence to rule of law, and an effective court system weighed most heavily in U.S. firm preferences."

However, there is no consistent evidence about the role of Rule of Law in determining FDI in different areas of the world. Fofana' ${ }^{[17]}$ empirical analysis revealed that "despite the abundance of natural resources in SubSaharan Africa, the quality of the legal system and the level of respect for the rule of law... are the main determinants that are statistically significant for the attraction of FDI in this region". But his empirical analysis on Western Europe shows that "the influence of the legal system and respect for the rule of law is not statistically significant."

Using a fixed effect model for panel data "on foreign direct investment inflows in 15 Asian economies for the period 1996-2007" with heteroskedasticity corrected standard errors, Mengistu and Adhikary ${ }^{[18]}$ reveal that Rule of Law is one key determinant of FDI inflows. In contrast, O'Neill ${ }^{[19]}$ analyzes "the politics of foreign direct investment from China to other developing states. Chinese outward FDI is positively correlated with political risk and increasingly destined for states with ... weak rule of law, factors that have been found to deter inward FDI". Panthamit and Chaiboonsri ${ }^{[20]}$ "identifies the main determinants of China's outward FDI activities with Greater Mekong Subregion countries, namely, Cambodia, Lao, Myanmar, Vietnam, and Thailand during the period between 2007 and 2016". Their study shows that higher rule of law "tends to decrease the probability of being a recipient of Chinese outward foreign direct investment." In more detail, Wang, Du and Wang ${ }^{[21]}$ study how institutions in the host countries affect the location choices of China's ODI (Outward Direct Investment), based on a deal-level sample from 2002-2011. They find that "China's ODI tends to avoid countries with strict legal systems. Tax evasion and resources are also major motives of China's ODI. General institutional quality and tax evasion are substitutes in China's ODI location decisions."

In addition, Rule of Law is a multidimensional concept covering a variety of components. Haggard and Tiede $^{[22]}$ find that "the correlation among different components of the rule of law concept" and economic growth are not tight. Following which, this paper tries to investigate the relations between different components of the Rule of Law and inward Foreign Direct Investment.

The main contribution of this paper are two points. First, we will investigate the relations between Rule of Law and inward FDI based on the data from the World Justice Project which is different from the data from the World Bank used by most scholars on this topic. Second, this paper decomposes the concept of Rule of Law into Constraints on Government Powers, Absence of Corruption, Open Government, Fundamental Rights, Order and Security, Regulatory Enforcement, Civil Justice, and Criminal Justice. We will study which factors have more significant impact on inward FDI.

The rest of the paper is organized as follows. Section 2 introduces the concept of Rule of Law and its factors, and the sources of the data. Section 3 presents some regression models to check the relations between Rule of Law and its factors with inward FDI. Finally, Section 5 concludes the paper and presents some discussion.

\section{THE DATA}

The data of this paper's object is mainly from the Rule of Law Index, which is an annual report by the World Justice Project. The index is constructed based on national surveys of households and legal practitioners around the world. The measure of this index is focused on "Effectiveness of law" in practice rather than "Law on books". The graph below shows the distribution of the overall score of Rule of Law over the world.

The framework of the main index is composed of eight factors:

The first factor measures the Constrains on Government Powers (CGP), which means "the government powers are effectively limited" by the legislature and the judiciary, independent auditing and review, "government officials are sanctioned for misconduct", "government powers are subject to nongovernmental checks", and "transition of power is subject to the law".

The second factor is Absence of Corruption (AOC), which covers government officials in the executive, judicial or legislative branch, in the police and the military, "do not use public office for private gain".

The third factor is Open Government (OPG). It includes "publicized laws and government data", "right 
to information", "civic participation", "complaint mechanisms".

The fourth factor Fundamental Rights (FUR) means "equal treatment and absence of discrimination", "due process of the law and rights of the accused", "the right to life and security of the person", "fundamental labor rights", freedom of opinion and expression, belief and religion, assembly and association, and from arbitrary interference with privacy is effectively guaranteed.

The fifth factor is Order and Security (OAS), which means "crime is effectively controlled", "civil conflict is effectively limited", and "people do not resort to violence to redress personal grievances".

The sixth factor is Regulatory Enforcement (REE), which means government regulations are "effectively enforced" and "applied and enforced without improper influence", "administrative proceedings are conducted without unreasonable delay", "due process is respected in administrative proceedings" and "the government does not expropriate without lawful process and adequate compensation".

The seventh factor Civil Justice (CIJ) means that "people can access and afford civil justice", civil justice is free of discrimination, corruption, improper government influence, is not subject to unreasonable delay and effectively enforced, and "alternative dispute resolution mechanisms are accessible, impartial, and effective".

The eighth factor is Criminal Justice (CRJ), which means "criminal investigation system is effective", "criminal adjudication system is timely and effective", "correctional system is effective in reducing criminal behavior", criminal justice system is "impartial", free of corruption and improper government influence, and has "due process of the law and rights of the accused".
The dependent variable of this study is the log of the FDI from the World derived by the reports of other Countries (W_OFDI_LN) which is from the International Monetary Fund.

To control the variation of other variables that may influence the level of inward FDI, the statistic model also encompasses the log of GDP (GDP_LN), the log of GDP per capita (GDP_PC_LN), the growth rate of GDP (GDP_G), the log of population (POP_LN), the log of the ratio of international trade over GDP (TRD GDP LN), the secondary school enrolment rate (SCH ENR). These data are from the World Bank and the United Nations Educational, Scientific and Cultural Organization. Due to the limited availability of the data, the models cover ninety-eight economies from 2014 to 2017.

\section{THE MODELS}

Since the object of this research is a panel dataset, we have tried Pooled Regression, Fixed Effects Regression, First Differencing Regression, Least Square Dummy Variable Regression, Random Effects Regression. From the Wooldridge test, we know that there is no autocorrelation of the data. From the F test and BreuschPagan test, we know that there are individual-specific effects, so we cannot apply the Pooled Regression. The Hausman Test suggest that the Fixed Effects Regression is better than the Random Effects Regression. So, we choose the Fixed Effects Regression with cluster-robust standard error (FE_r), which is more effective.

We add the overall score of Rule of Law and its eight composing factors one by one into the Fixed Effects Model, and get the result shown in the following table. From which, it is clear that Rule of Law (ROL) has significant positive impact on inward FDI. In details, Absence of Corruption (AOC), effective Regulatory Enforcement (REE), and Open Government (OPG) are positively influence the inward FDI, ceteris paribus.

Table 1. Regression results

\begin{tabular}{|c|c|c|c|c|c|c|c|c|c|}
\hline Variable & FE_r_ROL & FE_r_cGP & FE_r__AOC & FE_r_oGO & FE_r_FUR & FE_r_OAS & FE_r_REE & FE_r_cIJ & $\mathrm{FE}{ }_{1} r_{-} \mathrm{CRJ}$ \\
\hline GDP_LN & -1.2630771 & -1.1028776 & -.86210297 & -1.3510232 & -1.0473622 & -1.056596 & -1.108339 & -1.3446832 & -1.0135318 \\
\hline & 0.1488 & 0.2121 & 0.3182 & 0.1121 & 0.2220 & 0.2101 & $\begin{array}{r}0.2019 \\
0\end{array}$ & $\theta .1810$ & 0.2354 \\
\hline GDP_PC_LN & 1.7509772 & 1.5608803 & 1.2876725 & 1.8388189 & 1.4887136 & 1.508064 & 1.5274542 & 1.8138649 & 1.4485402 \\
\hline & 0.0732 & 0.1134 & 0.1840 & 0.0537 & 0.1204 & 0.1104 & 0.1149 & 0.1048 & 0.1259 \\
\hline GDP_G & - .01095571 & -.00975877 & -.01134457 & - .01064704 & - .0095287 & -.00974273 & -.0087649 & - . 0107261 & -.00938599 \\
\hline POP LN & $\begin{array}{r}0.3150 \\
5.5556387\end{array}$ & $\begin{array}{r}0.3633 \\
5.378489\end{array}$ & $\begin{array}{r}0.2827 \\
5.1642915\end{array}$ & $\begin{array}{r}0.3404 \\
5.5556353\end{array}$ & $\begin{array}{r}0.3715 \\
5.3053817\end{array}$ & $\begin{array}{r}0.3552 \\
5.3756133\end{array}$ & $\begin{array}{r}0.4173 \\
5.3953651\end{array}$ & $\begin{array}{r}0.3505 \\
5.5360788\end{array}$ & $\begin{array}{r}0.3647 \\
5.339284\end{array}$ \\
\hline & 0.0002 & 0.0002 & 0.0003 & 0.0001 & 0.0003 & 0.0002 & $\begin{array}{r}5.3953651 \\
0.0003\end{array}$ & $\begin{array}{r}5.5360 / 08 \\
0.0002\end{array}$ & $\begin{array}{r}5.3239204 \\
0.0002\end{array}$ \\
\hline TRD_GDP_LN & .27801493 & .24964136 & .234834441 & .28195633 & 2430417 & .24710091 & .26840719 & .29255554 & .24273171 \\
\hline SCH ENR & $\begin{array}{r}0.2061 \\
0\end{array}$ & $\begin{array}{r}0.2576 \\
\text { (0918941 }\end{array}$ & 0.2759 & 0.1884 & 0.2653 & 0.2488 & 0.2192 & 0.2266 & 0.2650 \\
\hline SCH_ENR & $\begin{array}{r}.00153059 \\
0.3087\end{array}$ & $\begin{array}{r}00189416 \\
0.2083\end{array}$ & $\begin{array}{r}.00223473 \\
0.1165\end{array}$ & $\begin{array}{r}.0007738 \\
0.5842\end{array}$ & .00168072 & .00181364 & . 00143515 & .00088713 & .00180264 \\
\hline ROL & 1.6239506 & 0.2083 & 0.1165 & 0.5842 & 0.2928 & $\theta .2271$ & 0.3319 & 0.5648 & 0.2257 \\
\hline CGP & & .28159373 & & & & & & & \\
\hline AOC & & & 1.0824576 & & & & & & \\
\hline OGO & & & & .62033142 & & & & & \\
\hline FUR & & & & 0.0117 & -20378645 & & & & \\
\hline OAS & & & & & & .13008833 & & & \\
\hline REE & & & & & & 0.7641 & 1.2956419 & & \\
\hline CIJ & & & & & & & 0.0374 & 1.1760861 & \\
\hline CRJ & & & & & & & & 0.1068 & -.20227666 \\
\hline _cons & $\begin{array}{r}-15.481007 \\
0.1167\end{array}$ & $\begin{array}{r}-15.302816 \\
0.1251\end{array}$ & $\begin{array}{r}-17.318883 \\
0.0847\end{array}$ & $\begin{array}{r}-13.376918 \\
0.1768\end{array}$ & $\begin{array}{r}-15.033116 \\
0.1105\end{array}$ & $\begin{array}{r}-15.894109 \\
0.1086\end{array}$ & $\begin{array}{r}-15.619769 \\
0.1190\end{array}$ & $\begin{array}{r}-13.502381 \\
0.1768\end{array}$ & $\begin{array}{r}0.7697 \\
-15.74945 \\
0.1053\end{array}$ \\
\hline
\end{tabular}




\section{CONCLUSION}

In order to attract more inward FDI into the host country, the overall level of Rule of Law should be enhanced. For which, corruption should be constrained, government regulations should be enforced effectively, and the governance should be more open.

\section{ACKNOWLEDGMENT}

This work was supported by Macau University of Science and Technology (Project code: FRG-19-037MSB).

\section{REFERENCES}

[1] M. Busse and C. Hefeker. "Political Risk, Institutions and Foreign Direct Investment." European Journal of Political Economy, vol. 23, no. 2, Elsevier B.V, 2007, pp. 397-415.

[2] A. Gani, "Governance and Foreign Direct Investment Links: Evidence from Panel Data Estimations." Applied Economics Letters, vol. 14, no. 10, Routledge, 2007, pp. 753-56.

[3] Q. Li, "Democracy, Autocracy, and Tax Incentives to Foreign Direct Investors: A Cross-National Analysis." The Journal of Politics, vol. 68, no. 1, Cambridge University Press, 2006, pp. 62-74.

[4] A.-A. Oliva and L. A. Rivera-Batiz. "Political Institutions, Capital Flows, and Developing Country Growth: An Empirical Investigation." Review of Development Economics, vol. 6, no. 2, Blackwell Publishers Ltd, 2002, pp. 248-62.

[5] J. S. Alexander, "The Rule of Law and Foreign Direct Investment in the Developing World." Order No. 3669354, University of California, Irvine, Ann Arbor, 2014

[6] N. Jensen, et al. Politics and Foreign Direct Investment, University of Michigan Press, 2012.

[7] W. J. Henisz, Witold J. "The Institutional Environment for Multinational Investment." Journal of Law, Economics, \& Organization, vol. 16, no. 2, Oxford University Press, 2000, pp. 334-64.

[8] M. S. Hossain and M. Z. Rahman, "Does Governance Facilitate Foreign Direct Investment in Developing Countries?" International Journal of Economics and Financial Issues, vol. 7, (1), 2017.

[9] S. K. S. Wilhelms, "Institutional FDI Fitness: Determinants of Foreign Direct Investment to Emerging Economies." Order No. 9831867, Fletcher School of Law and Diplomacy (Tufts University), Ann Arbor, 1998.
[10] A. A. Mengistu and B. K. Adhikary. "Does Good Governance Matter for FDI Inflows? Evidence from Asian Economies." Asia Pacific Business Review, vol. 17, no. 3, Taylor \& Francis Group, 2011, pp. 281-99.

[11] W. A. Naudé and W. F. Krugell. "Investigating Geography and Institutions as Determinants of Foreign Direct Investment in Africa Using Panel Data." Applied Economics, vol. 39, no. 10, Routledge, 2007, pp. 1223-33.

[12] A. Rodríguez-Pose and G. Cols. "The Determinants of Foreign Direct Investment in sub-Saharan Africa: What Role for Governance?" Regional Science Policy \& Practice, vol. 9, no. 2, Wiley Subscription Services, Inc, 2017, pp. 63-81.

[13] A. G. Yagoub and R. S. Abdulrazak, "The impact of governance on FDI flows to African countries," World Journal of Entrepreneurship, Management and Sustainable Development, vol. 8, (2), pp. 162169, 2012.

[14] M. EPAPHRA and J. MASSAWE, "The Effect of Corruption on Foreign Direct Investment: A Panel Data Study," Turkish Economic Review, vol. 4, (1), pp. 19-54, 2017.

[15] J. L. Staats and G. Biglaiser. "Foreign Direct Investment in Latin America: The Importance of Judicial Strength and Rule of Law.” International Studies Quarterly, vol. 56, no. 1, Blackwell Publishing Ltd, 2012, pp. 193-202.

[16] G. Biglaiser and J. L. Staats, "Do Political Institutions Affect Foreign Direct Investment? A Survey of U.S. Corporations in Latin America," Political Research Quarterly, vol. 63, (3), pp. 508522, 2010

[17] M. F. Fofana, "The Influence of Measures of Economic Freedom on FDI: A Comparison of Western Europe and Sub-Saharan Africa." Global Economy Journal, vol. 14, no. 3, De Gruyter, 2014, pp. 399-424.

[18] A. A. Mengistu and B. K. Adhikary. "Does Good Governance Matter for FDI Inflows? Evidence from Asian Economies." Asia Pacific Business Review, vol. 17, no. 3, Taylor \& Francis Group, 2011, pp. 281-99.

[19] D. C. O'Neill, "Risky Business: The Political Economy of China's Outward Foreign Direct Investment." Order No. 3398771, Washington University in St. Louis, Ann Arbor, 2010.

[20] N. Panthamit and C. Chaiboonsri, "China's Outward Foreign Direct Investment in the Greater Mekong 
Subregion," Journal of Economic Integration, vol. 35, (1), pp. 129-151, 2020.

[21] Y. Wang, J. Du and K. Wang, "The Determinants of Location Choices of China's ODI: Institutions, Taxation and Resources," Frontiers of Economics in China, vol. 10, (3), pp. 540-565, 2015.

[22] S. Haggard, and L. Tiede. "The Rule of Law and Economic Growth: Where Are We?" World Development, vol. 39, no. 5, Elsevier Ltd, 2011, pp. 673-85. 